Received: 28.04.2021.

doi: $10.46763 / J E S P T 211610065 n$

udc: $811.163 .3^{\prime} 37$

Revised: 16.05.2021.

Accepted: 26.05.2021.

\title{
PRIDE AND HUMILITY (semantic analysis of virtues and their antipodes)
}

\author{
Violeta Nikolovska ${ }^{1}$ \\ 'Faculty of Educational Sciences, Goce Delcev University, Stip, North Macedonia \\ violeta.nikolovska@ugd.edu.mk
}

\begin{abstract}
The aim of our research is the semantic field of the virtue dignity, with lexemes that are related and opposed to it (pride, ugly, beautiful, calm, humility, modest). Since this is a virtue, the analysis will be performed in a philosophical-theological context. We will also take into account the etymological analysis of the lexemes and the implications of their etymology in terms of semantics and vocabulary enrichment. The analysis will be performed based on the use of the lexemes from this semantic field in contexts of contemporary Macedonian language and literature.
\end{abstract}

Key words: virtue, dignity, humility, pride, beauty.

In the Interpretive Dictionary of the Macedonian language (IDML, A-ж, volume I, 2003:467) the term virtue is explained as: (lit.) Positive, good qualities, moral purity, innocence. In the Interpretive Dictionary of the Russian Language (Ожегов и Шведова 1993: 171) the explanation for the lexeme добродетель / virtue is: (lit.) Положительное нраственное качество, высокая нравственность. ${ }^{1}$ We cannot look at morality outside the theological- philosophical context. Therefore, in order to discover the content of the term virtue, we consulted theological literature. Saint Nectarios of Aegina speaks about virtues (excerpts from his book Know Thyself, in Hondropoulos 2007). St. Nectarios speaks of the virtues of the volitive and the emotional part of the soul. In respective articles he explains virtue as a notion, depicts the image of Christian virtue, the image of a virtuous man and the image of a Christian who died in virtue. We will quote a part of the text:"

"Virtue becomes according to what we seek and what we want. Hence, virtue (apetn) is what is

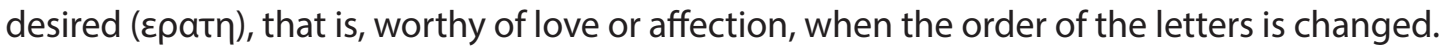

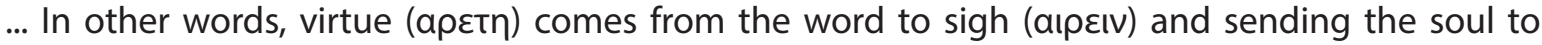
Heaven. Basil the Great says: Virtue is a wealth without a master, unimpeded and free from any need, that what is necessary and imposed cannot be virtue. Virtue is a measure between extremes in everything. A virtue could not be that which lacks a due measure, or that which exceeds that measure. When, for example, it comes to manhood, ${ }^{2}$ its disadvantage is cowardliness, and its excess is impertinence... And Chrysostom says: ... Virtue is unyielding and nothing can overcome it - neither slavery, nor shortening, nor poverty, nor disease, nor the greatest tyrant of all - death. Even there, virtue gives us security and stands by us. Virtue makes a man an angel and inspires the soul for heaven ... Cyril of Alexandria says this about virtue: There is meekness, humility, pursuit of justice, and a tongue that has given up speaking in vain, and thus also that which is sinful, but it is the doer of justice and truth, where there is eternal and most perfect virtue.' (Св. Нектариј Егински 2007: 399- 400).

\footnotetext{
${ }^{1}$ Positive moral value, high morality.

2 When talking about manhood, St. Nectarios of Aegina means courage: "Manhood is the undisturbed by fear before death, fearlessness in the face of adversity, courage before danger, and the choice of honorable death rather than shameful deliverance."(St.Nektarij Eginski 2007: 371).
} 
One of the virtues, according to St. Nectarios, of the emotional part of the soul is humility. We will determine the semantic characteristics of this virtue in relation to its antipode, pride. In the Old Slavonic language, the lexeme that denotes this term is: гръдыни $(f$.$) . Wanting to discover the etymology of this$ lexeme, we came up with the adjective zpd (ugly). In Skok's Dictionary (Skok, 1971: 613) for the lexeme грд we find the following meanings: 1 . Охол - conceited (with a note - only in books written in the church language); 2. Страшен - terrible (in Dubrovnik writers); 3. Изобличен, неприкладен, непријатен deformed, inappropriate, unpleasant (Serbian: neugodan), ugly (Serbian: ružan). According to Skok, the lexeme горд, and hence гордост and горделив, is a Russianism, which is used to mean'охол'(conceited). We did not find the lexeme охол in the Interpretive Dictionary of the Macedonian language. We found the lexemes горд and грд. Although they have the same etymological origin, they have semantically differentiated. One signifies a spiritualcharacteristic and the other a physical characteristic. According to the Interpretive Dictionary of the Macedonian Language (A-Ж, volume I:360), the lexeme zopd (proud) has the following meanings: 1 . One who has a high opinion of himself; 2 . One who is arrogant, proud; 3. One who is satisfied with the result of some work or success. The derivative горделив signifies only a spiritual characteristic with a negative connotation: One who is arrogant, pompous. Wehave not found the lexeme ropдocm (pride) in IDML, but we have found it in the Digital Dictionary of the Macedonian language, very precisely defined: Feeling of superiority over others. One of the seven deadly sins. The example given is: Pride comes before fall. In the Interpretive Dictionary of the Russian Language (Ожего и Шведова 1993: 139), there are two lexemes: гордость and гордыня, the second of which belongs to the high style. The meaning of гордоств is: 1. Чувство собственного достоинства, самоуважения. Национальная г. 2. Чувство удовлетворения от чего-н. Г. победдой. 3. Кого или чья. О том, кем (чем) гордятся. Зтот студент -2. института. 4. Высокомерие, чрезмерно высокое мнение о себе, спесь (разг.). Из-за своей гордости ни с кем не дружит. The lexeme гордыня is used exclusively with a negative connotation: Непомерная гордость (see 1st and 4th meaning). Обуздать свою гордыню.

Determining the meaning of the lexeme pride, the Interpretive Dictionary of the Russian Language led us to another lexeme from this semantic field, and that is the lexeme достоинство - dignity. We searched for the lexeme dignity in the corpus of examples in theDigital Dictionary of the Macedonian Language. ${ }^{3}$ According to the number of cited examples, and in relation to other lexemes from the modern Macedonian language, we could say that itsuse is not very frequent. ${ }^{4} \mathrm{~K}$. P. Misirkov uses it in "On Macedonian Matters": since we have people who think that the main dignity of a man is not to serve his people honestly, but to be shrewd, i.e. to lie both right and left...; The benefit for the people from scientific work of our intelligence will be seen from the fact that our people will be able to look at themselves and other nations with their own eyes, that they will recognize their own dignity and shortcomingsand the dignity and shortcomings of others. The lexeme dignity in other contexts of the contemporary Macedonian language: Ivan responded with the dignity of a reliable witness. Dignity did not allow him to show his suffering in front of others. The contexts in which we encounter the lexeme dignity (through positive and negative defining of what is, and what is not dignified) reveal the semantics of this lexeme: Without any dignity they poured out the source of gluttony, covetousness, greed, envy, betrayal, jealousy, adultery, the desire for power and wealth, selfishness, because they no longer know what they want, their vanity is uneasiness of mind, instability and constant restlessness, without the feeling for a sense of why they do not know how to satisfy their petty soul and turn the world into a hellish abyss. That is why the king respects their pure dignity more than your selfish vassalage; ... accordingto Article 25 of the Constitution of RM: "Each citizen is guaranteed the respect and protectionof the privacy of his/her personal and family life and of his/ her dignity and repute. In IDML (A-Ж, volume I: 529), the lexeme dignity is defined as: 1 . (only sg.) A positive trait confirmed by high moral values and self-esteem. He preserves his own dignity. He is a man of high dignity.

2. Positive trait, feature, quality. High artistic dignity. According to the Bulgarian Etymological Dictionary (BED) (A-3, 1971: 415), in the etymology of the lexeme dignity we find the prefixdo- (the meaning of the prefix do- is up to) and the root cros (stand) / in Russian croutb, the root which means 'cost,

\footnotetext{
${ }^{3}$ In our analysis, where it is not specifically emphasized, the examples are taken from the corpus of examples ofthe Digital Dictionary of the Macedonian language.

${ }^{4}$ Of course, for such a conclusion we should analyze of a wider corpus of examples of the modern Macedonian language.
} 
have a price, be worthy'. ${ }^{5}$ And in the Latin root also dignitas from dignus is 'valuable. ${ }^{6}$ What is the price of human dignity? We will look for the answer in a philosophical-theological context. Man was created in the Image of God. That is his dignity. That honor should not be defiled. That honor should be respected. We should not defile it ourselves, and we should respect it in others. It is simple. The image, or the reflection we might say, of God in us contains all the moral values contained in the notion of dignity. Interestingly, one of the meanings of the lexeme dignitas in Latin is 'beauty' (Grujić 1983:103). This brings us back to the lexeme гордост - pride that we saw as etymologically relatedto the lexeme грд ugly. The etymology of the lexemes we have studied shows us that the notions of beauty and ugliness primarily have a spiritual value.?

In the modern Macedonian language, the semantic difference between dignity and pride is lost. The lexeme pride is used with the meaning of the lexeme dignity: ... then her heart did not learn about pride, did not feel dignity, but shrank in the insurmountable grief andinsult because they, having their own country, their own roots soaked in the blood of so manyother heroes, in the letters wrote to her that they had died as Greeks for Greece. The tormented and suffering faces, on which the marks of pride and dignity are preserved, make you stand in front of them and stand upright with respect and restrained breath. As we noted above, the same phenomenon is found in the Russian language.

Pride, in Christian-theological sense, as mortal sin is the antipode of the virtue of humility. In Old Slavonic, the lexeme denoting this virtue is съмьрение (n.) (humility). ${ }^{8}$ If we analyze this lexeme morphologically, it consists of the prefix croccuring with the genitive andthe instrumental, and of the root in the base of which is the meaning ' the prefix cъ list the prepositions co - with and od - from. The lexeme мБра means 'measure' (Угринова - Скаловска 1979: 155) We will suggest a reading of this Old Slavic lexeme одмереност - modesty. This is in fact the definition of virtue, according to Basil the Great, as stated above:" A virtue could not be that which lacks a due measure, or that which exceeds that measure". In IDML the lexeme смирениe-humility does not exist, but there are adjectives смирен-смирениот and смирен-смирниот: calm - the calm (one). The difference in the use of the form of definiteness (смирениот / смирниот) reflects the difference in the meanings of this lexeme: one as a mental state (which is related with the meaning 'mup' - peace), and the other as a virtue in the Christian-theological sense: IDML (P-C, vol.V:459) - Смирен, смирениот adj. (calm - thecalm one) 1. The one who is filled with peace, tranquility, peaceful. Calm man. The calm crowd was slowly dispersing. Calm life. He entered the hall with calm feelings. 2. Which expresses peace, serenity. He spoke to the children in a calm voice. Calm look; - Смирен, смирниот adj. (modest, the humble one). The one who is submissive, modest, unblemished. Calm character. A pious, meek and humble old woman. Humble and gentle soul. In the InterpretiveDictionary of the Russian Language (Ожегов и Шведова 1993: 761) there is the lexeme смирение - humility. Its meaning is philosophically-theologically defined as 'отсуствие гордости' with the addition of 'оговность подчинятья чужой воле'. It also refers to the verb смириться: 'примириться $c$ кем-чем-н., покориться кому-чему н.'. Е.g.: Смириться с судьбой. Смириться перед неизбежностью. The adjective is смирный, with the meaning 'спокойный, тихй, покорный'. The Macedonian form смирен/смирниот - calm / the calm one could be considered as an influence from Russian literature. Meanings in interpretive dictionaries are obtained through an analysis of the use of lexemes in literature. We will look for the meaning of смирение - смирен humility - humble as a virtue in Christian literature. Inthe translation of the book "Know Thyself" by St. Nectarios of Aegina (in Hondropoulos 2007)the lexeme смерност modesty is used for this virtue. St. Nectarios says the following about modesty: "Modesty comes as a consequence of moral perfection. True modesty has its foundations in the inner man. It is the reflection of the inner grace of the soul, the radiance ofits virtues and its spiritual beauty. Like grace poured from within, it makes the face of the modest person bright and appealing. Modesty is a true picture of the character and a manifestation of the mental mood and inner majesty of the modest person. As it is

\footnotetext{
5 Aостен: worthy - 'who has the qualities to receive something' (according to BED, A-3: 415).

${ }^{6}$ https://www.google.com/search?q=dignity+etymology\&oq=dignity+et\&aqs=chrome.1.69i57j015.24279j0j8\&sourc eid=chrome\&ie $=$ UTF-8

${ }^{7}$ We have already talked about the relationship of beautiful and good, Nikolovska 2017 (http://eprints.ugd.edu. $\mathrm{mk} / 18647 /)$.

${ }^{8}$ In the dictionary attached in Угринова - Скаловска (1979: 163) it is modernized as смиреност (calmness).
} 
non- hypocritical and unspoiled, simple, and alien to exaggeration, it has a constant and unchanging character that never changes or transforms from modest to immodest, so it always remains the same. A modest person is uncunning, honest and direct. He follows the path of virtue and does good. He has a decent demeanor, a noble attitude, his words are measured,and his character instills confidence. His body posture is seemly and dignified and devoid of any bragging. The expression of his face is natural and unhypocritical, his gaze is cheerful, constant and incurious, the movements are measured and calm, the gait is natural and even,the movement is decorated with measure, and his winter and summer clothes are neat, modest, clean and simple. A modest person loves everyone and silently teaches them. "The modest man is a favorite of the people" (St. Nectarios of Aegina 2007: 431-432). In literature, in addition to the lexemes смирение, смерност there are also смиреномудрие (calm-wise) and смерноумие (calmness) ${ }^{9}$. In the Old Slavonic-Macedonian Dictionary (1999: 448-449) we find the lexemes: съмирение, съмьрение, съмБреномждростие, смБреномждрьствие. There is a semantic difference between the lexemes съмирение and съмьрение. The first is related to the root мup (peace) and has the meaning: 'reconciliation, peace' (Gr. Karadhayn). The second one, according to the meanings that are cited, tries to capture the meaning of humility: 'submissiveness, calmness, suffering, torment, compassion'. The Greek lexemes that are cited for this

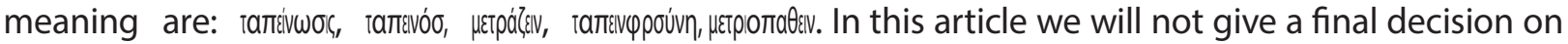
which lexeme we should use in order to denote this Christian virtue. Given the existence of two lexemes in the Old Slavic language as well, one which is associated with мир-(реасе)-съмирение, and the other as the name of the virtue - съмьрение, it may be good to use the lexemе смерност - humility (asin the translation of the book "St. Nectarios of Aegina - a saint of our time"). The lexeme oдмереност - modesty is most explicitly depicting the content of this virtue, yet it is more neutral in use, it is not associated with this meaning. Of course, it must necessarily enter intothe definition of the meanings of the lexemes добродетел аnd смерност - virtue and humility.

With the analysis we have presented here we have tried to give a semantic and cognitive analysis of virtue (from some of its aspects). What, among other things, the analysishas shown us is that the primary meanings of what is beautiful and ugly are spiritual, not physical and pleasing to the eye.

\section{References}

Gorgiev, Vl., Golubov., IV., Ilćev., St. (1971). Blgarski etimologićen rećnik, A-3, tom I, [Bulgarian etymological dictionary, A-3, tom], Sofija: Izdatelstvo na Bugarskata academia na naukite, https:// ibl.bas.bg/lib/ber/\#page/1/mode/1up

Digitalen rećnik na makedonskiot jazik, [Digital dictionary of the Macedonian language], http://www. makedonski.info/

St. Nektarij E., (2007), Poznaj se sebesi vo Hondropulos St. Nektarij Eginski: [svetitel od naše vreme, Skopje: Ǵakonija [St. Nectarios of Aegina Meet yourself in Hondropoulos, St Nectarios of Aegina: a saint of our time], Skopje: Deaconry

Nikolovska V., (2017). „Semantićkite komponenti na leksemata ubav” In: Meǵunarodna naućna konferencija "Minatoto na jazićniot svet - denes I utre", 15-16 Noemvri, 2017, Skopje,Makedonija , [The semantic components of the lexeme beautiful.] "In: International Scientific Conference"The Past of the Linguistic World - Today and Tomorrow ", November 15-16, 2017, Skopje, Macedonia.

St. Theophanes the Confessor, Archimandrite John Krestiankin 1995: 138-142. In the Serbian translations these have the forms: смјерно, смјерноумље, смиреномудрије.

Ozhegov, S. I. and Shvedova, N. Yu. (1993). Толковый словарь русского языка, Москва: Азъ, [Explanatory Dictionary of the Russian Language], Moscow: Az.

Despodova, V., (1999). Staroslovensko-makedonski rećnik, - Skopje: Institut za staroslovenska kultura: Matica makedonska. [Old Slovenian-Macedonian dictionary, - Skopje: Institute of Old Slovenian culture: Matica makedonska].

Sv. Teofan Zatvornik I Arhimandrit Jovan Kresjankin (1995), O pokajanju I ispovijesti, Cetinje: Svetigora

Koneski, K., (2003). Tolkoven rećnik,na makedonskiot jazik tom I, A-Ž, Skopje :Institut za makedonski jazik: „Krste Misirkov“. [Interpretive dictionary of the Macedonian language, volume I, A-Z.] Skopje: Institute for Macedonian Language "Krste Misirkov". 
Koneski, K., (2011). Tolkoven rećnik,na makedonskiot jazik tom V, P-C, Skopje :Institut za makedonski jazik: „Krste Misirkov“.[Interpretive dictionary of the Macedonian language, volume V, P-C.] Skopje: Institute for Macedonian Language "Krste Misirkov".

Urdinova, Skalovska, R., (1979). Staroslovenski jazik, Skopje: Univerzitet "Sv. Kiril I Metodij" [Old Slavic language], Skopje: University "Ss. Cyril and Methodius"

Grujić, B. (1983). Rečnik latinsko - srpskohrvatski, [Dictionary Latin - Serbo-Croatian] Cetinje: Obod.

Skok, P. (1971). Etimologijski rječnik hrvatskoga ili srpskoga jezika. Zagreb: Jugoslavenska akademija znanosti i umetnosti, tom I. [Etymological dictionary of the Croatian or Serbian language] Zagreb: Yugoslav Academy of Sciences and Arts, Volume I. 